\title{
Collaboration for good patient trajectories in the short-term ward of nursing homes
}

\section{Kari Brodtkorb}

Dosent

Institutt for helse- og sykepleievitenskap, Fakultet for helse- og idrettsvitenskap,

Universitetet i Agder, Grimstad

\section{Ragnhild Skaar}

\section{Førstelektor}

Institutt for helse- og sykepleievitenskap, Fakultet for helse- og idrettsvitenskap,

Universitetet i Agder, Grimstad

\section{Åshild Slettebø}

\section{Professor}

Institutt for helse- og sykepleievitenskap, Fakultet for helse- og idrettsvitenskap,

Universitetet i Agder, Grimstad

Observation research

\section{Ethnography}

\section{Organisation}

Collaboration

Nursing home

Sykepleien Forskning 202116 (83308) (e-83308)

DOI: 10.4220/Sykepleienf.2021.83308en

\section{Summary}

Background: Municipal short-term wards must safeguard the needs of patients with complex and unclear health conditions. Research shows that it is necessary to develop the capacity and quality of the services provided.

Objective: To explore the factors promoting good patient trajectories in a short-term ward at nursing homes. 
Method: The study had an ethnographic design with participant observation and interviews. The analysis revealed five categories and an overarching theme.

Results: Collaborating on systematisation and workflow in daily tasks, developing interprofessional cooperation, involving the patient and their family, collaborating across health service levels and maximising limited resources were factors that promoted a good patient trajectory.

Conclusion: Ensuring good patient trajectories in short-term wards is challenging, and limited resources appear to be a critical factor. Collaborative efforts from a number of actors are necessary to promote good patient trajectories.

Political and structural reforms affect the health services internationally (1) and nationally (2). The changes are due to a need for more complex health care for an ageing population, a decline in the number of hospital beds, and shorter periods of hospitalisation (3).

Since the introduction of the Coordination Reform (2), local authorities have experienced increased patient turnover and treatment responsibility. This has resulted in the provision of different short-term services (4) and differentiated services (5) in nursing homes. Some local authorities have succeeded in this respect (6), but research indicates that there are challenges linked to capacity, organisation and quality (7-11).

Today's health services are described as a complex system under pressure $(10,12)$ with many transitions in a patient trajectory (9). The multiple needs of patients require different skills and services at several levels. Greater efficiency is expected while at the same time quality must be maintained and improved, and new organisational solutions must be developed (12).

To deal with these challenges, Ingstad (13) asserts that the health and care services must be innovative. Rather than doing more and working faster, new work methods or forms of cooperation must be introduced. 
Allen (14) describes the key role of registered nurses (RNs) in organising the patient trajectory. While direct patient care is focused on the patient, and nursing home management focuses on the unit, organisational work addresses the management of patient trajectories. In organisations in the process of development, patient trajectories are often complex, and this is reflected in the efforts to organise them.

Good patient trajectories are characterised by complexity and coordination so that they promote collaboration, patient safety and satisfaction, and ensure effective utilisation of resources (9).

However, more knowledge is needed about the development of good patient trajectories in individual health and care services $(4,5,9)$, and for improvements in relation to holistic, coordinated and simpler patient trajectories (4). This will help to ensure that the change efforts taking place in the health services are evidence-based and appropriate.

\section{Objective of the study}

The objective of this study was, therefore, to explore factors that promote good patient trajectories in the short-term ward of the nursing home. The study was part of a major project dealing with social innovation in nursing homes.

An important finding about good patient trajectories, together with earlier research, formed the basis of the following research question: What organisational factors promote good patient trajectories in the shortterm ward of the nursing home?

\section{Method}


The study had an ethnographic design with participant observation and interviews at two nursing homes in a Norwegian municipality. The nursing homes were taking part in a research project funded by the Research Council of Norway: 'Social innovation in nursing homes' (allocation number 256647), and were chosen because they were exemplary nursing homes, known for their innovation and quality.

To meet the aim of the Coordination Reform, three long-term wards at the two nursing homes were converted in 2014 into short-term wards with a total of 29 beds. GP and RN density were strengthened, and the wards had access to physiotherapy and occupational therapy services.

The restructuring entailed major changes in the nursing staff's functions and responsibilities. The changes required substantial innovation, which had been ongoing for a period of three years prior to the start of the project. The short-term wards provided medical and rehabilitative services, with two beds designated for emergency help in the municipality.

The patients were transferred from hospitals for medical follow-up and/or rehabilitation, or from their homes for assessment and/or treatment of health conditions, adjustment of health needs or respite care. Their stay was time limited, varying from days to months, but usually between two and four weeks.

The wards had nurse managers who shared their time equally between management and clinical work. Some RNs had taken specialisation courses in cancer or intensive care nursing. Each nursing home had a fulltime doctor. Physiotherapists and occupational therapists were based outside the nursing home.

\section{Methodological approach}

Participant observation was used as the main methodological approach (15). In order to obtain additional data, we also conducted interviews with the managers of the institutions. 
The first and second authors conducted the interviews and observations. The observations took place over a period of 16 months from autumn 2016 to autumn 2018 , a total of 320 hours. We used an observation guide, based loosely on Polit and Beck (15).

In the observation notes, we focused on events and conversations such as collaboration between the staff and patients in different situations, and staff meetings and reports. In order to elucidate the activities of the actors, the guide showed who participated and what roles they played. In addition, theoretical, methodological and personal reflections were noted.

We developed a guide for the interviews based on the description of the nursing home, examples of innovation, innovation processes, innovation competence and conditions for innovation.

We took fieldnotes directly and edited them afterwards, or noted them in writing as soon after the event as possible. The researcher role varied from neutral observation to more participatory observation, and written accounts of conversations with different actors formed part of the data material. The interviews were recorded and written down verbatim.

\section{Data analysis}

The data were analysed in line with Graneheim and Lundman (16). First, we each read the fieldnotes in their entirety, followed by a joint readthrough where we identified data of relevance to our study.

Then we coded the meaning units, placing them in sub-categories. The sub-categories were merged into five categories, and an overarching theme was identified. The analysis resulted in the following categories:

- Collaborating on systematisation and workflow in daily tasks

- Developing interprofessional cooperation 
- Involving patients and their families

- Collaborating across health service levels

- Maximising limited resources

Together, the categories composed the overarching theme Collaboration promotes good patient trajectories (Table 1 ).

Table 1. Examples of the stages of analysis

\begin{tabular}{|c|c|c|c|}
\hline Coded meaning unit & Sub-category & Category & Theme \\
\hline $\begin{array}{l}\text { Healthcare personnel meet every day after morning care to } \\
\text { plan the rest of the day on the basis of a matrix board that } \\
\text { visualises key elements in the patients' trajectories. }\end{array}$ & $\begin{array}{l}\text { Daily matrix } \\
\text { board meetings }\end{array}$ & $\begin{array}{l}\text { Collaborate on } \\
\text { systematisation and } \\
\text { workflow in daily tasks }\end{array}$ & \multirow{5}{*}{$\begin{array}{l}\text { Collaboration } \\
\text { promotes } \\
\text { good patient } \\
\text { trajectories }\end{array}$} \\
\hline $\begin{array}{l}\text { Weekly interdisciplinary meeting in the ward attended by } \\
\text { the nurse manager, doctor, physiotherapist, occupational } \\
\text { therapist, RN from the home-based rehabilitation team and } \\
\text { a representative of the municipal contact office for welfare } \\
\text { and health services. }\end{array}$ & $\begin{array}{l}\text { Cooperation } \\
\text { structure }\end{array}$ & $\begin{array}{l}\text { Developing } \\
\text { interprofessional } \\
\text { cooperation }\end{array}$ & \\
\hline $\begin{array}{l}\text { The RN receives a telephone call from the family of a patient } \\
\text { who is becoming increasingly unsteady and has had a fall. } \\
\text { She describes the patient's situation and informs them that } \\
\text { the doctor will examine the patient. }\end{array}$ & $\begin{array}{l}\text { Daily } \\
\text { involvement }\end{array}$ & $\begin{array}{l}\text { Involving patients and } \\
\text { their family }\end{array}$ & \\
\hline $\begin{array}{l}\text { The doctor consults different specialists at the hospital } \\
\text { about the medical treatment of individual patients. }\end{array}$ & $\begin{array}{l}\text { Collaboration } \\
\text { with the hospital }\end{array}$ & $\begin{array}{l}\text { Collaborating across } \\
\text { health service levels }\end{array}$ & \\
\hline $\begin{array}{l}\text { The physiotherapy service was limited and was based } \\
\text { outside the ward. This created challenges in relation to } \\
\text { follow-up and continuity for patients on a rehabilitation } \\
\text { programme and for collaboration with ward staff. }\end{array}$ & $\begin{array}{l}\text { Meeting aimed } \\
\text { at elucidating } \\
\text { the challenges } \\
\text { and identifying } \\
\text { possible solutions }\end{array}$ & $\begin{array}{l}\text { Maximising limited } \\
\text { resources }\end{array}$ & \\
\hline
\end{tabular}

The project was approved by the Norwegian Centre for Research Data. Management gave written informed consent to taking part in the study. We informed management and staff about the study at dialogue meetings beforehand and during the project. They were aware that the project involved fieldwork, and that they could refuse to participate. Patients, their families and others were informed by means of notices in the wards.

\section{Results}

In the following, we present the categories and the overarching theme. 


\section{Collaboration on systematisation and workflow in daily tasks}

Systematisation in the daily work of the ward was crucial in creating good workflow and thereby patient safety, patient flow and good patient trajectories. To map patient trajectories, the staff used a matrix board that visualised these and created an overview.

The nurses said that daily sessions using the matrix board promoted joint assessments, and nutrition mapping and the use of checklists resulted in new and closer collaboration patterns. The fieldnotes showed that the doctor and RNs worked in close cooperation on medical treatment, medication reviews and treatment plans.

In the conversations, they stated that such forms of systematisation had been intentionally developed following the conversion of the wards into short-term wards. They added that it had been challenging but instructive for the staff, who were used to the work pace of the long-term ward.

In the interview, one manager said: 'We had to convert quickly from long-term to short-term wards without time to prepare the staff. It was a challenging process.'

In weekly interdisciplinary meetings, the situation of patients was reviewed by the nurse manager, doctor, physiotherapist, occupational therapist, RNs from the home-based rehabilitation team and a representative of the municipal contact office for welfare and health services.

Halfway through the nursing home stay, a meeting took place between the patient and their family, and relevant professionals and municipal bodies. Before the patients were discharged, staff on the ward held a meeting with community nursing services. 


\section{Developing interprofessional collaboration}

In connection with the conversion to short-term wards, each nursing home appointed a full-time doctor. In addition to being responsible for medical issues, the doctors were full members of the interdisciplinary team, and we observed that they were widely involved in the activities of the institution.

According to the doctors and nurse managers, they had a particularly close, trust-based cooperation. This was confirmed by our observations. In their combined nursing and management role, nurse managers experienced that they had a good overview of processes in the ward and were deeply involved in patient trajectories.

Physiotherapists and occupational therapists followed up patients by paying visits and when otherwise necessary, often in close cooperation with the primary contact and other nursing staff.

\section{«Due to the involvement of many actors, a collaboration structure was required.»}

Due to the involvement of many actors, a collaboration structure was required. As with daily nursing care meetings, interprofessional meetings were organised as informal meetings, where the situation of the individual patient was reviewed using the matrix board, and the care trajectory going forward was outlined.

Staff said that there was a good collaborative climate, and participants in the interprofessional meetings were active, attentive, unbiased and constructive. When there were signs of challenges in the collaboration, they tried to prevent conflicts through bridge-building measures and amicable solutions. 
For example, they arranged dialogue meetings when challenges arose in the cooperation with the physiotherapy service: 'The nurse manager stated that the physiotherapy service gave too little priority to continuity in the nursing home [...]. The therapists identified a potential for improvement in this respect,' (field notes).

At the meeting, it emerged that the challenge was linked to the total capacity in the municipality, but the parties agreed on various measures that could serve to improve the situation.

\section{Involving patients and their families}

The cooperation between patients and staff was fundamental, multifaceted and challenging. Staff involved patients and their families both on a daily basis and in scheduled meetings. In the interaction between nurses and patients related to personal hygiene and meals, we observed a general approach that was inclusive and dialogue-based.

Doctors routinely involved patients in questions about medical treatment and treatment plans. We observed close interaction between patients and physiotherapists in training sessions. Cooperation with families took place via telephone conversations and direct contact when family were visiting. Moreover, such involvement was integrated into the system.

Halfway through the nursing home stay, the patient and their family, relevant specialists and representatives of decision-making municipal bodies met in order to agree on the duration and content of the stay, and to reach a general conclusion about the future provision of services.

\section{«Staff involved patients and their families both on a daily basis and in scheduled meetings.»}


The form of collaboration was described in an interview with a manager as follows: 'We see how important it is to set goals together with the patient, and we don't decide for them what is important.'

The staff stated that they found the meetings important and challenging. They thought that both the patient and their family should feel well looked after, and strove to achieve a balance between their preferences and a fair use of the local authority's limited resources. They did not always succeed in reaching a conclusion everyone agreed with, and it was not always possible to meet the wishes of the family.

\section{Collaborating across health service levels}

The short-term wards had extensive collaboration with local municipal bodies. Staff at the municipal contact office for welfare and health services took part in the weekly interdisciplinary meetings. One of them described the meeting as crucial for reaching swift, collective decisions on care trajectories going forward, saying it was a big improvement.

Collaboration between the short-term wards and other municipal bodies took place by means of written internal memos and telephone conversations. The short-term ward also collaborated with hospitals. Admission and discharge were performed digitally through notices on nursing and care.

When required, ambulatory teams from the hospital's geriatric psychiatry department visited the short-term ward to work with individual patients. Some patients were hospitalised but many cases were dealt with in the wards.

The hospital doctors cooperated extensively with hospital specialists in the case of individual patients: 'The doctor is keen to maintain good contact with the hospital, and we find that doctors on both levels have been given more tasks [...]. Just after the meeting began, the doctor received a phone call from the hospital, and he left the meeting,' (field notes). 


\section{Maximising limited resources}

The most important resource in the ward was the general professional competence of the staff, and emphasis was put on enhancing this when the wards were converted to short-term wards. Medical and rehabilitation expertise was crucial in offering a wide range of treatments and ensuring good patient trajectories.

Some RNs had relevant specialisms, but according to one of the doctors, it was challenging that general medical competence was limited. They experienced challenges linked to basic staffing, RN coverage and the RNs' qualifications in emergency medical care.

\section{«Staffing challenges were handled by all staff demonstrating flexibility in their daily work.»}

GP density was good, but all the parties found that the physiotherapy service was inadequate. Staffing challenges were handled by the flexibility of all staff in their daily work, and the regular discussion of staffing and competence needs at management meetings:

'Most of the time at meetings is spent on clarifying what we want to report in terms of higher staffing needs $[. .$.$] . They agreed on what they should request,$ and together developed the arguments and wording they would use' (field notes).

We observed that non-conformance notices were used to put forward arguments for increased staffing. Management arranged ad-hoc meetings to deal with expected excess patients during public and annual holidays. The specialist competence of staff was highly valued, and staff shared this with other wards and the community nursing services.

\section{Collaboration promotes good patient trajectories}

When we summed up the categories, this overarching theme emerged. 
More systematic work methods entailed new and closer collaboration patterns among healthcare personnel, which promoted a better overview and improved patient safety and patient flow, resulting in a good patient trajectory. The daily interaction between the doctor and the RNs formed the core of interdisciplinary cooperation.

In addition, weekly interdisciplinary meetings, where the physiotherapist and the occupational therapist also participated, were important for patient flow and good patient trajectories.

The staff always involved patients and their families in decision-making processes and in work to achieve the desired health status, thereby paving the way for the patient's ownership of the care trajectory going forward.

A sound collaborative climate meant that staff used limited resources to the full, and ensured that overall competence was used for the good of the patient.

These factors show that the wards as a whole had an innovative approach to developing services, and that overall collaborative efforts helped to put in place the best possible patient trajectory (Figure 1). 


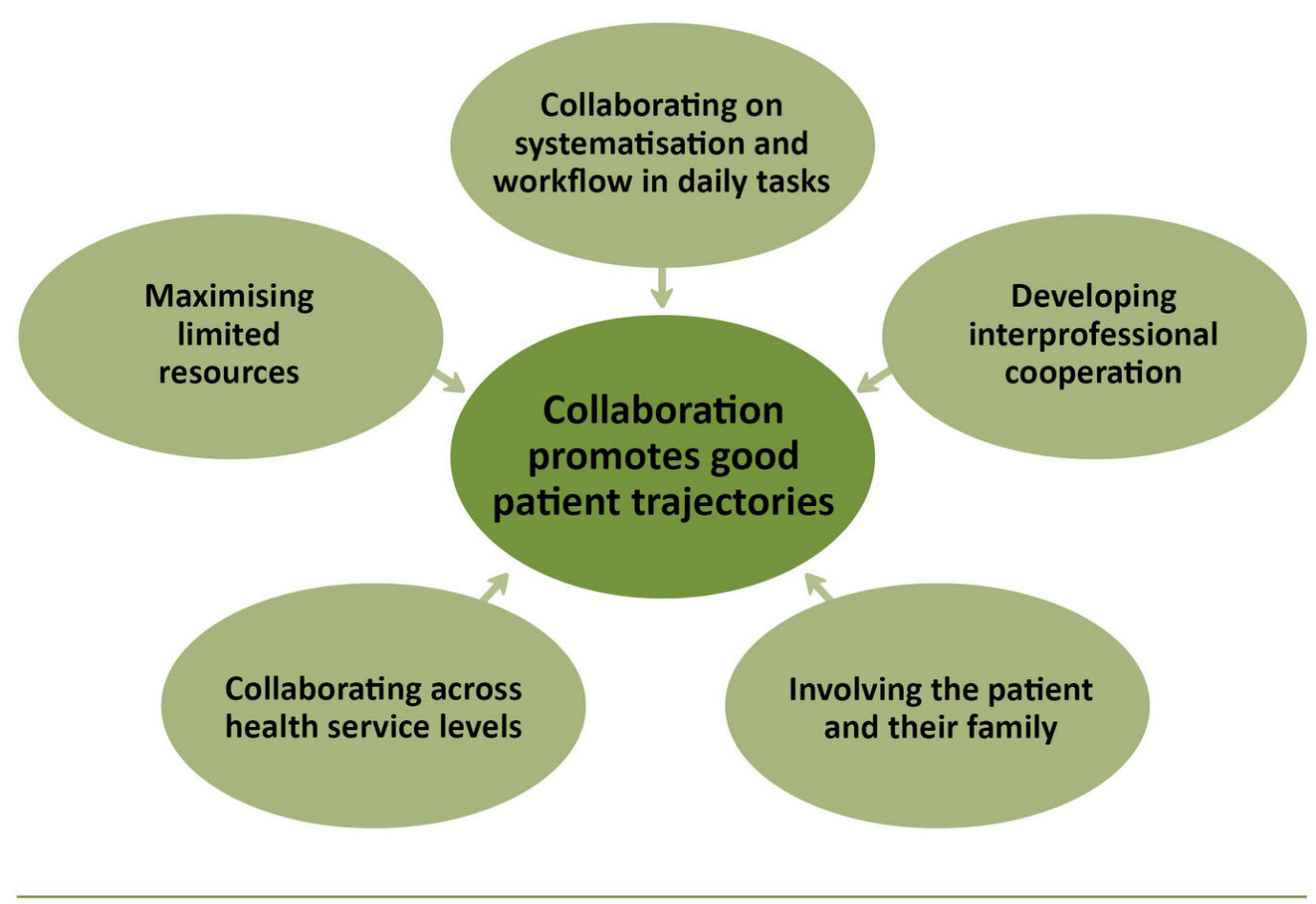

\section{Discussion}

The objective of this study was to explore the factors promoting good patient trajectories in a short-term ward at a nursing home.

Nursing home patients are particularly vulnerable to adverse events due to their complex, comorbidities (17), and there is reason to assume that the safety of patients who move between different service levels is under greater pressure.

Allen's (14) term 'trajectory complexity' seems to be precise in this connection. Her findings show that systematisation is a feature of daily work in the care group, the cooperation between doctor and $\mathrm{RN}$, and interdisciplinary cooperation and collaboration with external actors. 
Systematisation is in line with professional recommendations on standardised patient trajectories and the use of checklists in follow-up (8). Working methods appear to concur with what Allen refers to as safeguarding the patient trajectory, a practice characterised by sharing information and making necessary adjustments at the right time and right place (14).

\section{Interdisciplinary team meetings reduced friction}

The wards' interdisciplinary team held regular meetings. The fact that they met in person is highlighted as crucial to the work of providing a holistic patient trajectory for elderly people with chronic conditions (9).

The findings in our study show a tendency towards conflict in relation to the physiotherapy service. The authorities recognise that this is a challenge: the provision of physiotherapy in nursing homes has been substantially reduced and is absent in many places (18).

Bondevik et al. (17) found that healthcare personnel in Norwegian nursing homes, mainly RNs, nursing associates and healthcare assistants, gave a relatively low score to cooperation with doctors, physiotherapists and occupational therapists. In our study, attempts were made to solve such challenges through ongoing teamwork and through special measures.

Reeves (19) maintains that friction will arise between different practitioners, and that formal and open decision-making process are suited to building bridges and creating trust and team spirit between different occupational groups.

In general, our findings show that constant efforts to achieve a robust interdisciplinary community helps to ensure that patients get the help they need at the right time from those with the required competence. 


\section{The provision of care must be based on the patient's needs}

Ingstad (13) asserts that the patient must be the focal point of all collaboration if the goal is to achieve a holistic and good patient trajectory. Dialogue with patients and their families must be an integral part of the organisation of services.

Service user involvement is a key element in the modernisation of the public sector and entails that the needs of service users should be the focal point when the range of services is developed (17). This must be based on the patient's resources, needs and wishes (9).

The findings in our study demonstrate that this ambition has largely been fulfilled. Patients and their families were involved in choices, tasks and decisions a practice that corresponds to the ambition of making provision for a holistic patient trajectory for elderly patients with chronic diseases $(9,10)$.

The findings show that representatives of the municipal contact offices for welfare and health services participated in meetings at the short-term wards, and that cooperation between them and staff in the ward was good.

\section{«Patients and their families were involved in choices, tasks and decisions.»}

Cooperation with community nursing services was also systematised. This was in contrast to findings from earlier research, where collaboration between RNs in the short-term ward and the contact office in the municipality was inadequate $(6,20)$.

Terms such as 'cooperative practice' (21) and 'collaborative practice' (12) describe situations where health personnel from different professions interact with the patient and their family and the various professional communities of which the patient is a part. 
Kvangarsnes et al. (6) put forward the argument that such practices can also be understood as innovation. The terms seem to be applicable to the collaboration that took place between the actors in this study.

\section{Cooperation resulted in better utilisation of resources}

A summary of knowledge shows that adequate time and resources are vital in work on holistic patient trajectories for elderly individuals with chronic diseases (10). The findings in our study demonstrate that general resources were utilised in the best interests of the patients when healthcare personnel, patients and their families cooperated.

But it also emerged that the quality of services was challenged because medical and rehabilitative competence was limited. These challenges are reflected in studies showing a disparity between ambitions regarding municipal services and the competence of staff $(9,22,23)$.

Short-term wards are characterised by a faster pace, more difficult assessments and greater responsibilities (6) - features that are in line with Allen's term 'trajectory complexity' (14). Wards are also affected by a need for competence enhancement (6), low GP density, low staffing rates, use of unskilled labour and a lack of time (11).

Evidence suggests that there is currently a need for advanced clinical study programmes at master's degree level for RNs. These will provide broader competence than traditional specialisation courses $(3,12,20,24)$. Such study programmes are becoming more common in Norway and the Nordic countries, and doctors see RNs with these qualifications as a useful resource (25).

\section{Strengths and weaknesses of the study}


For ethical reasons, we did not carry out observations in the patient's room or in meetings of patients and their families. This may have limited the findings, in particular those linked to the involvement of patients and their families.

The validity of the study is strengthened by our arranging dialogue meetings with staff at the start of the study and underway where we presented preliminary findings, which were validated by staff.

The fact that all the researchers are RNs may have impacted on the findings. Researchers who carried out field observations and a researcher who did not do so took part in the analyses, and this may have led to a combined internal and external perspective.

The study was conducted at two nursing homes known for their innovation and good quality. This may limit the validity of the findings for organisations with a different starting point. However, we believe that the findings can have transfer value and inspire communities that want to introduce innovation to short-term wards.

\section{Conclusion}

Municipal short-term wards represent an important stage of the treatment chain, particularly for elderly people undergoing challenging life phases with complex health deterioration and an uncertain future. Ensuring good patient trajectories in such situations is important but challenging.

The study shows that collaboration on systematisation and workflow in daily tasks, the development of interprofessional cooperation, the involvement of patients and their families, collaboration across health service levels, and the maximisation of limited resources were factors that helped to promote good patient trajectories. 
The organisation of a patient trajectory required collaborative efforts from several actors. Limited staffing and competence appear to be factors requiring further attention in clinical practice and research going forward.

\section{References}

1. Rantz ML, Popejoy L, Vogelsmeier A, Galambos C, Greg A, Flesner $\mathrm{M}$ et al. Successfully reducing hospitalization of nursing home residents: results of the Missouri Quality Initiative. Journal of the American Medical Directors Association. 2017;18(11):960-6. DOI: 10.1016/j.jamda.2017.05.027

2. St.meld. 47 (2008-2009). Samhandlingsreformen. Rett behandling - på rett sted - til rett tid. Oslo: Helseog omsorgsdepartementet; 2009.

3. Finnbakk E, Skovdal K, Blix ES, Fagerstrøm L. Top-level managers' and politicians' worries about future care for older people with complex and acute illness - a Nordic study. International Journal of Older People Nursing. 2012;7(2):163-72.

4. Helsedirektoratet. Samhandlingsstatistikk 201415. Oslo: Helsedirektoratet; 2016. Available at: https://helsedirektoratet.no/publikasjoner/samhandlin gsstatistikk (downloaded 03.10.2019).

5. Tingvold L, Magnussen S. Økt spesialisering og differensiering i sykehjem. Hvordan løses dette i ulike kommunale settinger? Tidsskrift for omsorgsforskning. 2018;4(2): 153-64.

6. Kvangarsnes M, Hole T, Teigen S, Teige BK. Samhandlande praksis som innovasjon. Erfaringer med $\varnothing$ yeblikkelig hjelp døgnopphald i kommunar i rurale strøk. In: Kvangarsnes M, Håvold JI, Helgesen $\varnothing$, eds. Innovasjon og entreprenørskap - Fjordantologien. Oslo: Universitetsforlaget; 2015. 
7. Bruvik F, Drageset J, Abrahamsen JF. Fra sykehus til sykehjem - hva samhandlingsreformen har ført til. Sykepleien Forskning. 2017;12(60613):(e-60613). DOI: $\underline{10.4220 / \text { Sykepleienf.2017.60613 }}$

8. Dale B, Folkestad B, Førland O, Helles $\varnothing$ R, Moe A, Sogstad M. Er tjenestene fortsatt «på strekk»?: om utviklingstrekk i helse- og omsorgstjenestene i kommunene fra 2003 til 2015. Senter for omsorgsforskning; 2015. Rapportserie nr. 12/2015.

9. Danielsen KK, Nilsen ER, Fredwall, TE. Pasientforl $\varnothing \mathrm{p}$ for eldre med kronisk sykdom. Omsorgsbiblioteket. Senter for omsorgsforskning, sør: 2017.

10. Pedersen KR. Hvilke kunnskapsmessige utfordringer ligger i sykepleiernes arbeid på en korttidsavdeling i sykehjem? [Master's Thesis]. Troms $\varnothing$ : Universitetet i Troms $\varnothing$, Det helsevitenskapelige fakultet, Institutt for helse- og omsorgsfag; 2012.

11. Killie PA, Debeasay J. Sykepleieres erfaringer med samhandlingsreformen ved korttidsavdelinger på sykehjem. Nordisk tidsskrift for helseforskning. 2016;12(2). DOI: $\underline{10.7557 / 14.4052}$

12. Bukve $\mathrm{O}$, Kvåle G, eds. Samhandling og kvalitet i helseorganisasjoner. Oslo: Universitetsforlaget; 2014.

13. Ingstad K. Organisasjon og ledelse i helsefag og sykepleie. Oslo: Gyldendal Akademisk; 2010.

14. Allen D. Care trajectory management: a conceptual framework for formalizing emergent organisation in nursing practice. Journal of Nursing Management. 2018;27(1):4-9. DOI: 10.1111/jonm.12645

15. Polit DF, Beck CT. Nursing research: generating and assessing evidence for nursing practice. 10th ed. Philadelphia: Wolters Kluwer; 2017. 
16. Graneheim UH, Lundman B. Qualitative content analysis in nursing research: concepts, procedures and measures to achieve trustworthiness. Nurse Education Today. 2004;24(2):105-12. DOI:

10.1016/j.nedt.2003.10.001

17. Bondevik GT, Hofoss D, Huseb $\varnothing$ BS, Deilkås ECT. Patient safety culture in Norwegian nursing homes. BMC Health Services Research. 2017;17:424.

18. Willumsen E, Ødegård A, eds. Tverrprofesjonelt samarbeid - et samfunnsoppdrag. Oslo:

Universitetsforlaget; 2016.

19. Meld. St. 26 (2014-2015). Fremtidens primærhelsetjeneste - nærhet og helhet. Oslo: Helseog omsorgsdepartementet; 2015.

20. Reeves. Sosiologisk forståelse av tverrprofesjonell utdanning og praksis. In: Willumsen E, Ødegård A, eds. Tverrprofesjonelt samarbeid - et samfunnsoppdrag. Oslo: Universitetsforlaget; 2016. pp. 146-61.

21. Myhr HR. Tverrfaglig samarbeid i et helhetlig pasientforløp - en studie av beslutningsprosesser i et kommunalt tverrfaglig team [Master's Thesis]. Trondheim: Norges teknisknaturvitenskapelige universitet, Fakultet for samfunnsog utdanningsfag, Institutt for sosialt arbeid; 2017. Available at: http://hdl.handle.net/11250/2569316 (downloaded 24.02.2020).

22. Willumsen E, Sirnes T, Ødegård A. Nye samarbeidsformer - et samfunnsoppdrag. In: Willumsen E, Ødegård A, eds. Tverrprofesjonelt samarbeid - et samfunnsoppdrag. Oslo: Universitetsforlaget; 2016. pp. 17-32.

23. Bing-Jonsson P, Foss C, Bjørk IT. The competence gap in community care: imbalance between expected and actual nursing staff competence. Nordic Journal of Nursing Research. 2015;36(1):27-37. 
24. Kyrkjebø D, Søvde BE, Råholm M-B.

Sjukepleiarkompetanse i kommunehelsetenesta: Er det rom for fagleg oppdatering? Sykepleien Forskning. 2017;12(64027):(e-64027). DOI:

$\underline{10.4220 / \text { Sykepleienf.2017.64027 }}$

25. Hauge S, Hestetun M, Kirkevold M. Avansert geriatrisk sykepleie - hva er det og hvorfor trenger vi slike sykepleiere i Norge? Geriatrisk sykepleie. 2011;3(1):20-3.

26. Smailhodzic E. Behov for avansert kliniske sykepleiere innen eldreomsorgen i Norden. En kvalitativ studie ut fra legens perspektiv [Master's Thesis]. Høgskolen i Sørøst-Norge, Fakultet for helsevitenskap; 2016. 